\title{
Treatment with digoxin and measurement of serum digoxin levels after myocardial infarction
}

\author{
D. N. Sharpe, ${ }^{1}$ R. M. Norris, and B. McL. White \\ From the Department of Medicine, University of Auckland Medical School, the Coronary Care Unit, Green \\ Lane Hospital, and the Department of Nuclear Medicine, Auckland Hospital, Auckland, New Zealand
}

Forty-nine patients admitted to a Coronary Care Unit with myocardial infarction complicated by left ventricular failure, were treated with $1.75 \mathrm{mg}$ Lanoxin over 36 hours. Serum digoxin levels were measured by radioimmunoassay at 8,24 , and 48 hours. No difference in serum levels was observed between those patients who received 'old' (reduced bioavailability) and those who received 'new' Lanoxin. Serum levels were significantly higher at 8 and 24 hours in those patients who received their first dose intramuscularly compared with those who received their first dose orally, irrespective of the bioavailability of the oral preparation used. No correlation was observed between serum digoxin levels and serum urea or creatinine during the 48-hour period of study. The incidence of arrhythmias is reported, but no conclusion can be drawn as to whether or not the glycoside contributed to this in any way. The use of digoxin in patients with acute myocardial infarction complicated by left ventricular failure is justifiable in the light of available evidence. However, in view of the possible predisposition of such patients to toxicity, lower serum levels than were achieved in many of our patients seem desirable, and a modified dosage schedule is suggested.

Controversy concerning the indications for, and effectiveness of, digitalis therapy in patients with acute myocardial infarction still exists, as does concern about enhanced toxicity in such patients. Early investigations (Bing et al., I950; Blain et al., 1956; Sarnoff et al., 1964) suggested that digitalis had no effect on, or else reduced, myocardial oxygen consumption $\left(\mathrm{MVO}_{2}\right)$, which was inconsistent with the observations that the drug augmented the velocity of fibre shortening, which is an important factor in determining $\mathrm{MVO}_{2}$ (Sonnenblick et al., 1965). More recent work has demonstrated that while digitalis significantly increases $\mathrm{MVO}_{2}$ in the nonfailing canine heart, it has no effect on, and in some cases reduces $\mathrm{MVO}_{2}$ in the failing heart (Covell et al., 1966). This is presumably caused by a reduction in end-diastolic volume and hence systolic tension which offsets the increase in $\mathrm{MVO}_{2}$ caused by increased contractility.

Early experimental evidence indicated that digitalis facilitated ectopic activity in the presence of infarction (Bellet, Johnston, and Schecter, 1934; Travell, Gold, and Modell, 1938), and more recent

Received 17 July 1974.

1 This work was done in part during tenure of a National Heart Foundation of New Zealand Research Fellowship. evidence has suggested that the intoxicating dose is reduced by about one-third after acute myocardial infarction (Morris et al., 1969).

While routine use of digitalis in uncomplicated myocardial infarction is contraindicated, its use early in the treatment of heart failure and cardiomegaly complicating acute myocardial infarction seems justifiable in the light of available evidence (Ratshin et al., 1971; Karliner and Braunwald, 1972). This study was planned in order to gain some idea of the serum digoxin levels obtained in patients who were given digoxin after acute myocardial infarction complicated by left ventricular failure.

\section{Patients and methods}

Forty-nine patients were admitted to a coronary care unit between November 1971 and March 1973 with myocardial infarction and left ventricular failure. The presence of myocardial infarction was diagnosed on the basis of characteristic clinical presentation, electrocardiographic and serum enzyme changes. Left ventricular failure was manifested by dyspnoea, gallop rhythm, pulmonary venous congestion, and usually interstitial oedema, or frank pulmonary oedema. Digoxin was administered according to a routine protocol using Lanoxin tablets and intramuscular preparation (Burroughs Wellcome \& Co.). The total dose was $1.75 \mathrm{mg}$, given in divided doses of $0.75 \mathrm{mg}, 0.5 \mathrm{mg}, 0.25 \mathrm{mg}$, and 
$0.25 \mathrm{mg}$ at $0,8, \mathrm{I} 6$, and 36 hours, respectively. The time between the onset of infarction and the first dose of digoxin varied from 6 hours to 7 days, the interval for most cases being between 24 and 48 hours. The first dose was given either intramuscularly or orally in a random order. After the 48-hour study period further dosage of digoxin was judged on an individual basis and in some cases the drug was discontinued. No patient subsequently received more than $0.25 \mathrm{mg}$ daily. All patients were receiving oral frusemide 40 to $80 \mathrm{mg}$ daily which was started either at the start of digoxin administration or up to 24 hours previously. Oral potassium supplements ( $48 \mathrm{mmol}$ daily) were given routinely as Slow K tablets (Ciba).

Serum digoxin, urea, creatinine, and potassium levels were measured immediately before the first dose of Lanoxin, and 8, 24, and 48 hours later. All serum digoxin estimations were made at least 8 hours after the previous dose of Lanoxin. The serum digoxin was measured in duplicate by radio-immunoassay (Smith, Butler, and Haber, 1969), using antibody supplied from St. Bartholomew's Hospital, London. Serum urea, creatinine, and potassium were measured on an SMA 6-60 autoanalyser. A note was made of other treatment administered during the period of observation and the patients' electrocardiographs were monitored continuously for arrhythmias, an hourly rhythm strip being recorded in each case.

In May 1972, the process of manufacturing Lanoxin tablets was changed, so that a new oral preparation having twice the bioavailability of the old preparation was produced. In fact, this change restored the bioavailability of digoxin from Lanoxin tablets to the level which existed until 1969 (Johnson et al., 1973). The Lanoxin tablets in our Hospital were changed for the new preparation in August 1972, and checks with the Hospital pharmacy and Burroughs Wellcome \& Co. (N.Z.) Ltd. confirmed that all tablets supplied after this date were of the new bioavailability standard. We elected to continue our trial with the new preparation, though the change had not been anticipated at the start of the study. No change was made in the intramuscular preparation used throughout the period of study.

Twenty-six patients received the 'old' oral preparation, 14 having their first dose orally, and 12 their first dose intramuscularly. Twenty-three received the 'new' oral preparations, II having their first dose orally, and 12 their first dose intramuscularly. The serum digoxin levels were compared in all four groups, and correlated with serum urea and creatinine levels and cardiac arrhythmias.

\section{Results}

The serum digoxin level in all patients was zero at the start of the period of study and the levels in each group at 8,24 , and 48 hours are shown in Table I and the Fig. No significant differences in serum digoxin levels at 8, 24, and 48 hours between those receiving the 'old' and 'new' oral preparations were observed. When patients having their first dose of either preparation orally were compared with those having their first dose intramuscularly, however, levels were significantly higher in the latter group at 8 hours $(2.5 \mathrm{nmol} / 1(1.95 \mathrm{ng} / \mathrm{ml})$ compared with $\mathrm{r} .35 \mathrm{nmol} / \mathrm{l}(\mathrm{r} .05 \mathrm{ng} / \mathrm{ml}) ; \mathrm{P}<0.00 \mathrm{r})$, and 24 hours (3.01 $\mathrm{nmol} / \mathrm{l}(2.35 \mathrm{ng} / \mathrm{ml})$ compared with $1.79 \mathrm{mmol} / 1$ ( $1.5 \mathrm{ng} / \mathrm{ml} ; \mathbf{P}<0.005)$. This difference was less pronounced and not significant at 48 hours (2.5 nmol/1 compared with $2.0 \mathrm{nmol} / \mathrm{l}$; P > 0.1 and less than 0.2). All groups were comparable with respect to age and serum urea and creatinine measured at the start of the period of study (Table 2). No significant correlation was found between the serum digoxin levels and the serum urea or creatinine, and no patient had a serum potassium level less than

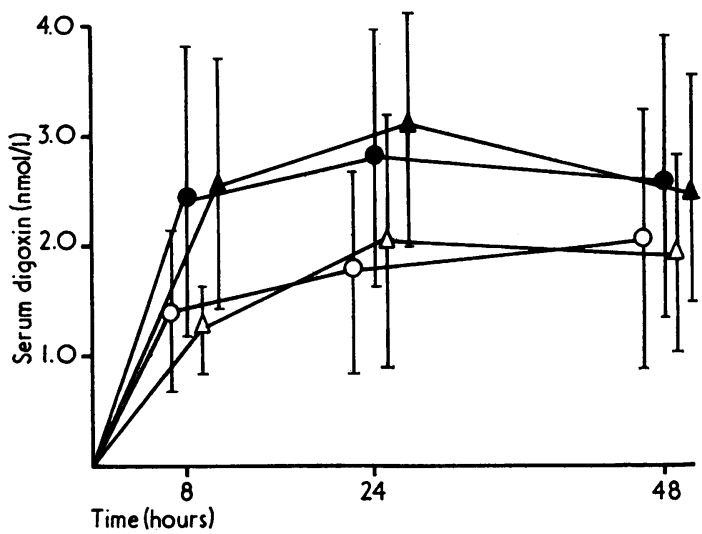

FIG. Mean $( \pm S D)$ serum digoxin concentrations. Closed circles = 'Old' Lanoxin first dose I.M. Open circles = 'Old' Lanoxin first dose oral Closed triangles = 'New' Lanoxin first dose I.M. Open triangles = 'New' Lanoxin first dose oral

TABLE I Serum digoxin concentrations in nmol/l (figures are mean $\pm S D$ in each group)

\begin{tabular}{|c|c|c|c|c|}
\hline & Serum digoxin & 8 hours & 24 hours & 48 hours \\
\hline $\begin{array}{l}\text { 'Old' } \\
\text { Lanoxin }\end{array}$ & $\begin{array}{l}\text { First dose I.M. } \\
\text { First dose oral }\end{array}$ & $\begin{array}{l}2.43 \pm I .28 \\
I .40 \pm 0.78\end{array}$ & $\begin{array}{l}2.81 \pm 1.10 \\
1.79 \pm 0.91\end{array}$ & $\begin{array}{l}2.56 \pm 1.32 \\
2.05 \pm 1.13\end{array}$ \\
\hline $\begin{array}{l}\text { 'New' } \\
\text { Lanoxin }\end{array}$ & $\begin{array}{l}\text { First dose I.M. } \\
\text { First dose oral }\end{array}$ & $\begin{array}{l}2.56 \pm 1.19 \\
1.28 \pm 0.36\end{array}$ & $\begin{array}{l}3.07 \pm 1.02 \\
2.04 \pm 1.19\end{array}$ & $\begin{array}{l}2.43 \pm 1.04 \\
1.92 \pm 0.93\end{array}$ \\
\hline
\end{tabular}

Conversion SI Units to Traditional Units - digoxin I $\mathrm{nmol} / 1 \approx 0.78 \mathrm{ng} / \mathrm{ml}$. 
TABLE 2 Serum urea and creatinine concentrations

\begin{tabular}{|c|c|c|c|c|}
\hline & & $\begin{array}{l}\text { Mean age } \\
(y r)\end{array}$ & $\begin{array}{l}\text { Serum urea } \\
\text { (mmol/l) } \\
\text { Mean (SD) }\end{array}$ & $\begin{array}{l}\text { Serum creatinine } \\
(\mu \text { mol } / l) \\
\text { Mean }(S D)\end{array}$ \\
\hline 'Old' Lanoxin & $\begin{array}{l}\text { First dose I.M. } \\
\text { First dose oral }\end{array}$ & $\begin{array}{l}62.7 \\
62.8\end{array}$ & $\begin{array}{l}8.5(3.2) \\
7.5(3.2)\end{array}$ & $\begin{array}{l}132.6(35.4) \\
150.3(44.2)\end{array}$ \\
\hline 'New' Lanoxin & $\begin{array}{l}\text { First dose I.M. } \\
\text { First dose oral }\end{array}$ & $\begin{array}{l}62.3 \\
57.4\end{array}$ & $\begin{array}{l}8.1(2.5) \\
7.3(3.3)\end{array}$ & $\begin{array}{l}123.8(26.5) \\
123.8(35.4)\end{array}$ \\
\hline
\end{tabular}

Conversion SI Units to Traditional Units - I $\mu \mathrm{mol}$ creatinine $\approx 0.01 \mathrm{I} \mathrm{mg}$ I mmol urea $\approx 6.0 \mathrm{mg} / 100 \mathrm{ml}$.

$3.5 \mathrm{mmol} / 1$ (normal range $3.5-4.9 \mathrm{mmol} / \mathrm{l}$ ) at any time during the 48-hour period of observation.

Thirteen patients were seen to have cardiac arrhythmias during the 48-hour period of observation as noted in Table 3. All three patients who had heart block had inferior infarcts. The patient who had asystole had an anteroseptal infarct with right bundle-branch block, a transvenous pacemaker having been inserted prophylactically before digoxin administration (Norris, Mercer, and Croxson, 1972). This patient was paced through the period of asystole but died 28 days later. Only one death occurred during the 48-hour period of digoxin treatment, from cardiogenic shock, but 13 patients died in hospital from 2 to 28 days after the initial standard digoxin administration was completed.

\section{Discussion}

The similarity of serum digoxin levels observed between our patients who received oral loading doses of the 'old' and 'new' Lanoxin preparations was surprising. The increased bioavailability of the new

TABLE 3 Arrhythmias

\begin{tabular}{lll}
\hline & & $\begin{array}{l}\text { Serum digoxin } \\
\text { (nmol/l) before develop- } \\
\text { ment of arrhythmia }\end{array}$ \\
\hline Paroxysmal atrial & & \\
$\quad$ tachycardia & 2 & $3.22,3.46$ \\
Atrial fibrillation & 3 & $0.64^{\star}, 2.18^{\star}, 2.30$ \\
Atrial flutter & I & $2.30^{\star}$ \\
Second degree heart block & I & 1.28 \\
Complete heart block & 2 & $1.28^{\star}, 1.79$ \\
Bigeminy & I & 2.56 \\
Ventricular tachycardia & 2 & $1.02,1.79$ \\
Asystole & I & $4.61^{\star}$ \\
\hline \multicolumn{1}{c}{ Total } & I3 & \\
\hline
\end{tabular}

* Serum digoxin concentration at 8 hours.

Remainder - Serum digoxin concentration at 24 hours.

Conversion SI Units to Traditional Units - digoxin $1 \mathrm{nmol} / 1 \approx$ $0.78 \mathrm{ng} / \mathrm{ml}$.
Lanoxin preparation has been confirmed in several studies on patients receiving maintenance digoxin (Stewart and Simpson, 1972; Whiting, Rodger, and Sumner, 1972; Falch, Teien, and Bjerkelund, 1973), and in normal volunteers receiving loading doses (Falch et al., 1973; Johnson et al., 1973). However, our comparatively infrequent estimations of serum digoxin levels at 8,24 , and 48 hours after the initial dose may have provided an insufficient estimate of bioavailability. Better indices of bioavailability would have been provided by more frequent estimation of the serum digoxin level, and measurement of the area under the serum concentration/ time curve and measurement of urinary digoxin excretion (Huffman and Azarnoff, 1972; Falch et al., 1973; Sanchez et al., 1973; Greenblatt et al., I973). The fact remains, however, that plasma levels were no different between the two preparations at the three times that they were measured.

The serum digoxin levels in those patients who received their first dose intramuscularly was higher than expected when compared with those who received their first dose orally, suggesting that the gastrointestinal absorption of the drug may be reduced in this group of patients. While it could be argued that this difference is caused by the delayed peak serum level reflecting a longer distribution and binding half-time of the drug when given by the intramuscular route, it is unlikely that any such difference would be present to such a significant degree at 8 and 24 hours after the initial intramuscular or oral dose. Single dose studies in healthy subjects have shown that the bioavailability of digoxin tablets is approximately half that of an equivalent dose given by the intramuscular route (Greenblatt et al., 1973), and in patients with heart failure as a result of myocardial infarction, absorption of the oral preparation is likely to be further reduced and less predictable. While digoxin is incompletely absorbed when given by the intramuscular route (Doherty and Perkins, 1965), and bioavailability is less compared with intravenous infusion of an equivalent dose (Greenblatt et al., 
1973), the very high serum levels which are transiently produced after intravenous infusion would seem undesirable in this situation. Therefore, where rapid achievement of tissue-plasma equilibrium and optimal therapeutic levels is required as in this group of patients with heart failure caused by myocardial infarction, administration of the initial dose of digoxin intramuscularly seems preferable to oral or intravenous administration.

Accepting the evidence which suggests that patients with myocardial infarction are predisposed to digoxin toxicity (Morris et al., 1969), one might have preferred to have seen serum digoxin levels slightly lower than were achieved in the majority of our patients who received their first dose intramuscularly; this suggests that a dose smaller than that used in our study is desirable. No conclusion can be drawn as to whether or not digoxin contributed to arrhythmias in our patients; the routine administration of potassium supplements and absence of hypokalaemia may be relevant in this respect. The lack of correlation between serum digoxin levels and serum urea and creatinine throughout the period of study further supports the recommendation of an empirical initial dose regimen in the acute situation. The concept of total body digoxin concentration relates to maintenance therapy only, and lean body mass is the only relevant factor to be considered in calculating a loading dose.

We suggest that the use of digitalis in left ventricular failure complicating myocardial infarction is reasonable, but its routine usage in the uncomplicated situation is not justifiable. We recommend that where digoxin treatment of such patients is contemplated, a total dose of no more than $1.5 \mathrm{mg}$ (compared with $1.75 \mathrm{mg}$ in this study) be administered during the first 36 hours, the first dose being $0.5 \mathrm{mg}$ intramuscularly and the remainder being given in divided doses orally. Further dosage should be judged according to clinical response, body weight, and renal function, and wherever possible a 24-hour serum level should be measured to assist in this respect.

The antibody used in the radio-immunoassay for serum digoxin was supplied by Dr. Douglas Chamberlain and Mr. Michael Howard at St. Bartholomew's Hospital, London.

\section{References}

Bellet, S., Johnston, C. G., and Schecter, A. (1934). Effect of cardiac infarction on the tolerance of dogs to digitalis. Archives of Internal Medicine, 54, 509.

Bing, R. J., Maraist, F. M., Dammann, J. F., Jr., Draper, A., Jr., Heimbecker, R., Daley, R., Gerrard, R., and Calazel, P. (1950). Effect of strophanthus on coronary blood flow and cardiac oxygen consumption of normal and failing human hearts. Circulation, 2, 513.

Blain, J. M., Eddleman, E. E., Siegel, A., and Bing, R. J. (1956). Studies on myocardial metabolism: V. The effects of lanatoside-C on the metabolism of the human heart. fournal of Clinical Investigation, 35, 314 .

Covell, J. W., Braunwald, E., Ross, J., Jr., and Sonnenblick, E. H. (I966). Studies on digitalis: XVI. Effects on myocardial oxygen consumption. Fournal of Clinical Investigation, 45, 1535 .

Doherty, J. E., and Perkins, W. H. (1965). Studies following intramuscular tritiated digoxin in human subjects. American fournal of Cardiology, 15, 170.

Falch, D., Teien, A., and Bjerkelund, C. J. (1973). Comparative study of the absorption, plasma levels, and urinary excretion of the 'new' and 'old' Lanoxin. British Medical fournal, I, 695.

Greenblatt, D. J., Duhme, D. W., Koch-Weser, J., and Smith, T. W. (1973). Evaluation of digoxin bioavailability in single-dose studies. New England fournal of Medicine, 289, 65I.

Huffman, D. H., and Azarnoff, D. L. (1972). Absorption of orally given digoxin preparations. Fournal of the American Medical Association, 222, 957.

Johnson, B. F., Fowle, A. S. E., Lader, S., Fox, J., and Munro-Faure, A. D. (1973). Biological availability of digoxin from Lanoxin produced in the United Kingdom. British Medical fournal, 4, 323.

Karliner, J. S., and Braunwald, E. (1972). Present status of digitalis treatment of acute myocardial infarction. Circulation, 45, 891.

Morris, J. J., Taft, C. V., Whalen, R. E., and McIntosh, H. D. (1969). Digitalis and experimental myocardial infarction. American Heart fournal, 77, 342.

Norris, R. M., Mercer, C. J., and Croxson, M. S. (1972). Conduction disturbances due to anteroseptal myocardial infarction and their treatment by endocardial pacing. American Heart fournal, 84, 560.

Ratshin, R. A., Russell, R. O., Jr., Kaymakcalan, S., and Rackley, C. E. (197I). The effects of digoxin on left ventricular performance in myocardial infarction and cardiogenic shock. Clinical Research, 19, 335.

Sanchez, N., Sheiner, L. B., Halkin, H., and Melmon, K. L. (1973). Pharmacokinetics of digoxin: interpreting bioavailability. British Medical fournal, 4, 132.

Sarnoff, S. J., Gilmore, J. P., Wallace, A. G., Skinner, N. S., Jr., Mitchell, J. H., and Daggett, W. M. (1964). Effect of acetyl strophanthidin therapy on cardiac dynamics, oxygen consumption and efficiency in the isolated heart with and without hypoxia. American fournal of Medicine, 37, 3.

Smith, T. W., Butler, V. P., Jr., and Haber, E. (I969). Determination of therapeutic and toxic serum digoxin concentrations by radioimmunoassay. New England fournal of Medicine, 281, 1212.

Sonnenblick, E. H., Ross, J., Jr., Covell, J. W., Kaiser, G. A., and Braunwald, E. (1965). Velocity of contraction as a determinant of myocardial oxygen consumption. American fournal of Physiology, 209, 919.

Stewart, M. J., and Simpson, E. (1972). New formulation of Lanoxin: expected plasma levels of digoxin (letter). Lancet, 2, 54I.

Travell, J., Gold, H., and Modell, W. (1938). Effect of experimental cardiac infarction on response to digitalis. Archives of Internal Medicine, 61, 184.

Whiting, B., Rodger, J. C., and Sumner, D. J. (1972). New formulation of digoxin (letter). Lancet, $2,922$.

Requests for reprints to Dr. R. M. Norris, Green Lane Hospital, Auckland, New Zealand. 